\title{
Treatment of Cattle from Bovicoliosis
}

\author{
F. S. Pulotov \\ Scientific Research Veterinary Institute, Head of the Laboratory of Arachnoentomology and \\ Acarology, Candidate of Veterinary Sciences (PhD).
}

\begin{abstract}
The article provides information on the therapiya of the common bovicoliosis among cattle.

Key words: Parasite, insects, bovicola, desinsection, fauna, intensive, extensive, pitetroid, pyrethrin, permethrin.

\section{Introduction}

In recent years, in almost all countries of the world, the attention of scientists and specialists to herbal pyrethroid drugs has been growing. The active ingredient in this group of drugs are pyrethrins, which are esters of transchrysanthemum monocarboxylic and transpirinic acids. These drugs are superior to other chemicals of the chemical group in their relative safety and high insecticidal efficacy even in small doses, safety for humans, wildlife and the environment. It is characterized by a high insecticidal effect against organochlorine, organophosphorus, benzimidazole, carbamate compounds. 10-100 times lower doses, even more effective at concentrations. The number of measures for disinsection and decontamination is reduced by 2,5-3 times.

Currently, in the fight against ectoparasites of cattle in livestock farms, nurel-D, arrivo, ectomin, karatin, deltamethrin, sumicidin, ambush, ripcord, decis and local cypermethrin, sumi-alpha (Navoi electrochemical plant "SE-EJSC"), permethrin. - Pyrethroid drugs are widely used, such as the Indian joint venture "VINUZ" LTD, Bukhara). However, according to the analysis of scientific literature, the therapeutic and insecticidal effect of pyrethroid drugs against bovicoliosis disease in the country has not yet been studied.

Research method. Insect species collected in the laboratory of arachnoentomology. Handbook and identification tables ("Key to the chewing lice (Mallophaga) of domestic animals". Identified using the fauna of the USSR. M., - L.: Edition of the Academy of Sciences of the USSR, 1940; Puff lice. Part 1. Edition of the Academy of Sciences of the USSR, 1959, Blagoveshchensky D.I.) and other specialized literature.

Research results. It turned out that ecto- and endoparasites, belonging to 12 species, are widespread in livestock farms of the republic, of which the most common pathogen is Bovicola bovis. Experiments on the study of the insecticidal properties of pyrethroid drugs in the laboratory Recently synthesized and resynthesized pyrethroids (arrivo, ectomin, nurel-D, sumi-alpha, permethrin-10 and cypermethrin in laboratory conditions) against bovicola bovis in cattle, as a result, have been determined to be at least effective $(100 \%)$ concentration of these drugs (Table 1$)$.
\end{abstract}


Experimental study of the insecticidal effect of pyrethroid drugs on Bovicola bovis in laboratory conditions

Table 1

\begin{tabular}{|c|c|c|c|c|c|c|c|c|}
\hline \multirow[t]{2}{*}{ S.n. } & \multirow[t]{2}{*}{ Name of drugs } & \multicolumn{7}{|c|}{$\begin{array}{l}\text { The form of an aqueous emulsion, the effectiveness of the } \\
\text { insecticide, } \%\end{array}$} \\
\hline & & 0,015 & 0,02 & 0,025 & 0,03 & 0,035 & 0,05 & 0,1 \\
\hline 1 & Arrivo & $\mathrm{LD}_{90}$ & $\mathrm{LD}_{100}$ & $\mathrm{LD}_{100}$ & $\mathrm{LD}_{100}$ & $\mathrm{LD}_{100}$ & $\mathrm{LD}_{100}$ & $\mathrm{LD}_{100}$ \\
\hline 2 & Ectomin & $\mathrm{LD}_{30}$ & $\mathrm{LD}_{40}$ & $\mathrm{LD}_{45}$ & $\mathrm{LD}_{45}$ & $\mathrm{LD}_{50}$ & $\mathrm{LD}_{60}$ & $\mathrm{LD}_{100}$ \\
\hline 3 & Nurel-D & $\mathrm{LD}_{80}$ & $\mathrm{LD}_{85}$ & $\mathrm{LD}_{90}$ & $\mathrm{LD}_{95}$ & $\mathrm{LD}_{100}$ & $\mathrm{LD}_{100}$ & $\mathrm{LD}_{100}$ \\
\hline 4 & Sumi-alpha & $\mathrm{LD}_{50}$ & $\mathrm{LD}_{75}$ & $\mathrm{LD}_{95}$ & $\mathrm{LD}_{100}$ & $\mathrm{LD}_{100}$ & $\mathrm{LD}_{100}$ & $\mathrm{LD}_{100}$ \\
\hline 5 & Permethrin-10 & $\mathrm{LD}_{40}$ & $\mathrm{LD}_{45}$ & $\mathrm{LD}_{50}$ & $\mathrm{LD}_{55}$ & $\mathrm{LD}_{60}$ & $\mathrm{LD}_{100}$ & $\mathrm{LD}_{100}$ \\
\hline 6 & Cypermethrin & $\mathrm{LD}_{90}$ & $\mathrm{LD}_{95}$ & $\mathrm{LD}_{100}$ & $\mathrm{LD}_{100}$ & $\mathrm{LD}_{100}$ & $\mathrm{LD}_{100}$ & $\mathrm{LD}_{100}$ \\
\hline
\end{tabular}

As a result, aqueous emulsions of arrivon $-0,025$, ectomine $-0,1$, nurel-D $-0,035$, sumi-alpha 0,03 , permethrin-10 - 0,05 and cypermethrin - 0,025 have $100 \%$ insecticidal action against cattle bovicoles detected in the laboratory.

Currently, water-based forms of synthetic pyrethroid drugs are widely used, however, the use of these drugs in the cold season can lead to a cold snap in cattle, as well as to colds and various respiratory diseases. Therefore, instead of this liquid (water-based) method for the treatment and prevention of bovicoliosis in cattle, it is advisable to use the dry (powder) method, that is, insecticidal (dust) powder of drugs belonging to the group of synthetic pyrethroids. Because it is possible to treat livestock for this disease using these insecticides in powder form not only in the summer, but also in the winter months, that is, without hesitation throughout the year.

With this in mind, a powdered insecticide was prepared from synthetic pyrethroid (permethrin-10 and cypermethrin) drugs in the laboratory, and their insecticidal activity against Bovicola bovis was determined, resulting in a minimum effective $(100 \%)$ concentration of these drugs (Table 2 ).

Experiments to determine the effectiveness of powder insecticides against Bovicola bovis in the laboratory

Table 2

\begin{tabular}{|c|c|c|c|c|c|c|c|}
\hline \multirow{2}{*}{ S.n } & Name of drugs & \multicolumn{6}{|c|}{ Powdered form, insecticide efficiency, \% } \\
\cline { 3 - 8 }$\cdot$ & & $\mathbf{0 , 0 1}$ & $\mathbf{0 , 0 2}$ & $\mathbf{0 , 0 3}$ & $\mathbf{0 , 0 4}$ & $\mathbf{0 , 0 5}$ & $\mathbf{0 , 0 6}$ \\
\hline 1 & Permethrin -10\% EC & LD $_{50}$ & LD $_{60}$ & LD $_{80}$ & LD $_{90}$ & LD $_{95}$ & LD $_{100}$ \\
\hline 2 & Cypermethrin - 25\% EC & LD $_{50}$ & LD $_{70}$ & LD $_{90}$ & LD $_{95}$ & LD $_{100}$ & LD $_{100}$ \\
\hline
\end{tabular}

As a result, it was found that the concentrations of permethrin-10 - 0,06 and cypermethrin - 0,05\% in powdered insecticides have a $100 \%$ insecticidal effect against cattle under laboratory conditions.

More than 6385 head of cattle were tested in production conditions in Taylak, Urgut, Samarkand and Pastdargom districts of Samarkand region, Kitab of Kashkadarya region, Bakhmal of Jizzakh region, Denov district of Surkhandarya region. At the same time, the minimal and $100 \%$ insecticidal effect of pyrethroid drugs was tested directly on cattle under laboratory conditions and high efficiency was achieved (Table 3).

Therapeutic efficacy of pyrethroid drugs against bovicoliosis in an industrial setting 
Table 3

\begin{tabular}{|c|c|c|c|c|c|c|c|c|c|}
\hline \multirow[b]{3}{*}{$\dot{\overrightarrow{\dot{\theta}}}$} & \multirow{3}{*}{  } & \multirow{3}{*}{ 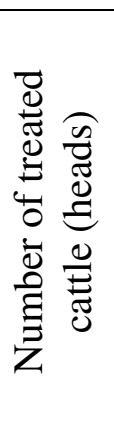 } & \multirow{3}{*}{ 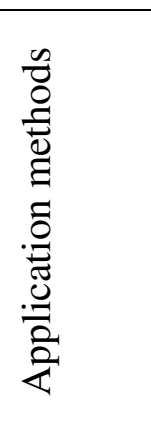 } & \multirow{3}{*}{ 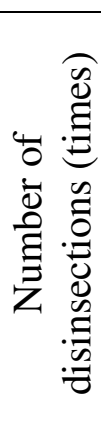 } & \multicolumn{4}{|c|}{ Application form } & \multirow{3}{*}{ 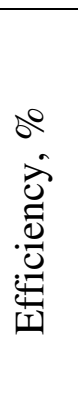 } \\
\hline & & & & & \multicolumn{2}{|c|}{$\begin{array}{l}\text { aqueous } \\
\text { emulsion }\end{array}$} & \multicolumn{2}{|c|}{ in powder form } & \\
\hline & & & & & 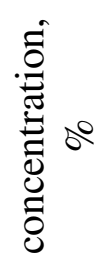 & 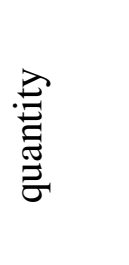 & 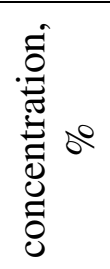 & 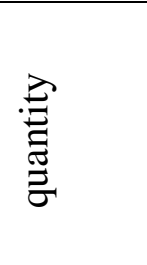 & \\
\hline 1 & $\begin{array}{l}\text { Arrivo - } \\
25 \mathrm{EC}\end{array}$ & 1585 & $\begin{array}{c}\text { Sprayin } \\
\mathrm{g}\end{array}$ & 2 & 0,02 & $\begin{array}{c}1-4 \\
1 / \text { head }\end{array}$ & - & - & 100 \\
\hline 2 & $\begin{array}{l}\text { Ectomin } \\
100 \mathrm{EC}\end{array}$ & 570 & $\begin{array}{c}\text { Sprayin } \\
\mathrm{g}\end{array}$ & 2 & 0,1 & $\begin{array}{c}1-4 \\
1 / \text { head }\end{array}$ & - & - & 100 \\
\hline 3 & $\begin{array}{l}\text { Nurel-D } \\
50 \text { EC }\end{array}$ & 1290 & $\begin{array}{c}\text { Sprayin } \\
\mathrm{g}\end{array}$ & 2 & 0,035 & $\begin{array}{c}1-4 \\
1 / \mathrm{head}\end{array}$ & - & - & 100 \\
\hline 4 & $\begin{array}{c}\text { Sumi-alpha - } \\
20 \text { EC }\end{array}$ & 1100 & $\begin{array}{c}\text { Sprayin } \\
\mathrm{g}\end{array}$ & 2 & 0,03 & $\begin{array}{c}1-4 \\
1 / \mathrm{head}\end{array}$ & - & - & 100 \\
\hline \multirow[t]{2}{*}{5} & \multirow[t]{2}{*}{$\begin{array}{l}\text { Permethrin - } \\
10 \mathrm{EC}\end{array}$} & 219 & $\begin{array}{c}\text { Sprayin } \\
\mathrm{g}\end{array}$ & 2 & 0,05 & $\begin{array}{c}1-4 \\
1 / \text { head } \\
\end{array}$ & - & - & 100 \\
\hline & & 144 & $\begin{array}{c}\text { Water } \\
\text { through } \\
\text { cheesec } \\
\text { loth }\end{array}$ & 2 & - & - & 0,06 & $\begin{array}{c}200- \\
500 \\
\text { g/head }\end{array}$ & 100 \\
\hline \multirow[t]{2}{*}{6} & \multirow[t]{2}{*}{$\begin{array}{l}\text { Cypermethrin - } \\
25 \mathrm{EC}\end{array}$} & 1224 & \begin{tabular}{|c} 
Sprayin \\
$\mathrm{g}$
\end{tabular} & 2 & 0,025 & $\begin{array}{c}1-4 \\
1 / \text { head }\end{array}$ & - & - & 100 \\
\hline & & 253 & $\begin{array}{l}\text { Water } \\
\text { through } \\
\text { cheesec } \\
\text { loth }\end{array}$ & 2 & - & & 0,05 & $\begin{array}{l}200- \\
500 \\
\text { g/head }\end{array}$ & 100 \\
\hline
\end{tabular}

\section{Conclusions:}

1. Water-emulsion forms of Arrivo - 0,02, ectomine - 0,1, nurel-D - 0,035, sumi-alpha - 0,03, permethrin - 0,05 and cypermethrin $-0,025 \%$ were administered to each adult cattle against bovicoliosis disease 2,0-4,0 liters, 1,0. -2,0 liters for small ruminants ( 2 times with an interval of $10-14$ days) gives a $100 \%$ curative effect.

2. In the cold season, in the form of an insecticidal powder (dust) of local permethrin-10-0,06 and cypermethrin - 0,05\% (100-500 g / head, 2 times with an interval of 10-14 days), treatment of cattle against bovicoles is effective $100 \%$ entomocide.

\section{List of used literature:}

1. Blagoveshchensky D.I. "Keys to the chewing lice (Mallophaga) of domestic animals." Fauna of the USSR. M., - L.: Academy of Sciences of the USSR publishing house, 1940.

2. Ganiev I.M., Aliverdiev A.A. "Atlas of ixodoid ticks", M. "Kolos", 1968, 110-111 p.

3. Ruzimurodov A. The laws of evolution and zoobiodiversity. Zarafshan Publishing House, Samarkand, 2008. 
4. Ruzimuradov A. Biological parasitism. Optimization of livestock breeding, House of Culture publishing house "Zarafshon", Samarkand, 2011.

5. Akbaev R.M., Pugovkina N.V. "Bovikolez of cattle in livestock farms of the Moscow region" // Journal "Veterinary", Publishing house "Logos Press" (Moscow), - 2017.- № 1, - p. 10-13.

6. Ruzimurodov A., Rakhimov M., Ismoilov A., Abdullaeva D., Pulatov F. Monograph. Pyrethroids. Protection against natural and infectious diseases. Zarafshan Publishing House, Samarkand, 2018. 